Jurnal Poetika Vol. IV No. 2, Desember 2016

\title{
READING SIMULATION IN YANN MARTEL'S Life Of Pi
}

\author{
Sri Nurhidayah \\ STKIP Bina Insan Mandiri Surabaya \\ nurhidayahsri@gmail.com
}

\begin{abstract}
Abstrak
Penelitian ini bertujuan untuk mengungkapkan (1) bagaimana simulasi diterapkan dalam novel Life of Pi dan (2) apa dampak simulasi dalam novel Life of Pl? Dengan pendekatan Baudillard mengenai simulasi, simulakra dan hiper-realitas, kedua cerita dipersilangkan dan menciptakan kekacauan realitas dari cerita Pi dan perjuangan hidupnya. Dengan kata lain, hasil yang dapat ditemukan adalah simulasi yang merupakan penceritaan kembali kisah yang lain dengan konflik dan plot yang sama, menjelaskan proses terbentuknya kebenaran yang bersayap. Artinya adalah, kedua cerita tersebut dapat menjadi benar dan salah—-sebuah hiper-realitas karena yang sebenarnya hanya terdapat pada pengalaman Pi yang sudah terlindas dalam simulakra atau penceritaan Pi.
\end{abstract}

Kata Kunci : Simulasi, Simulakra, Hiper-realitas dan Cerita.

\section{Abstract}

This research aimed to show (1) how is simulation applied in Life of Pi and (2) what are the impacts of the simulation in Life of Pi? By Baudillard's approach of simulacra, simulasi and hyper-reality, these two stories are crossed over one another and created chaotic reality of Pi's story of his survival. In the other word, the result is that the simulation, which is Pi's retelling of another story with same conflicts and plots, explained the process of the blurred real reality. It means that those stories can be both true and false - a byper-reality, because the real one is always inside of Pi's experienced which is swallowed by the simulacra or Pi's retelling.

Keywords: Simulation, Simulacra, Hyper-reality and the Stories.

\section{Introduction}

In the novel, Martel told the story of Pi's survival floating on a boat by the Pacific Ocean for about seven months together with a Bengal tiger. This story dominates the whole part of the novel. Pi explained the details of how he had survived with the animals until he was saved by Mexican people when he lands. However, Pi compulsively told another story contains of similar plots with different characters because the Japanese officers from the Tsimsum cargo company (that brought Pi, his family and the animal sailing the Ocean), do not believe in Pi's story with the Bengal tiger (and the animals).

Instead of keep telling his story with animals, he told another story in order to gain trust from the Japanese officers. Pi told a story that he had survived with a broken leg Oriental man, a Cook, Pi's mother, and Pi himself. The Cook killed the Oriental man because he was afraid of having no food, then Pi's mother got angry. The Cook even killed Pi's mother. Here, Pi cannot control himself and finally killed the Cook. This story also tells about the brutality that happened on the lifeboat, it is also caused by the feeling to survive. It is exactly similar to the story told in the novel when Pi survives with a broken leg Zebra, female Orangutan, the Hyena and Richard Parker (the Bengal Tiger). The Hyena eats the Zebra, the Orangutan gets angry and the Hyena eats the Orangutan. Finally, the Tiger jumps out of the tarpaulin to eat the Hyena. 
Here, Martel's explanation about "hard to believe" should be seen as the most important thing here, because he tried to explain something which is beyond logic, especially about something that happened to Pi and his life. It can be impossible to believe but from the rational explanation told by $\mathrm{Pi}$, this impossibility could be possible. Here is the ambiguity, the fictional and the factual cases which are exposed and opposed in this novel, brings the situation of duality where the truth is floating and uncertain, "Moreover, in the book's final chapters, just when many novels are winding down to their foregone conclusions, Martel gives "'Life of Pi"' an intriguing twist, after the lifeboat comes safely to shore in Mexico (and Richard Parker disappears without ceremony into the jungle)" (Krist, 2002, The New York Times).

The other side of the story becomes the central point in making the reader confused. It seems that this novel is actually told the story of $\mathrm{Pi}$ and those people (like it is told to the Japanese officers), however the story is considered to be too rough then Martel decided to change the story into Pi and the animals. Of course, it is just an assumption but it has made the ambiguity of this novel, as if the novel did not have the certain truth of the story; whether it is $\mathrm{Pi}$ and the animals or it is about Pi and the people. The important thing is that those two stories have brutalities that involved $\mathrm{Pi}$ in the survival on the Pacific Ocean. The two have similarities and those lead to what McHale previously stated the characteristics of postmodern fiction which is blurring the fact and the fiction, the real and the imagination, and the truth and the ambiguity.

The important points about this novel that should be underlined is a fact that it can be said as a postmodern fiction. It provides two stories, and it has the blurred boundary between fact and fiction (rational and imaginative). Therefore, according to these aspects and facts, this study will try to explore the relation among those in a simple question about the real story happens in the novel. This problem is between the real reality and the representation of the reality is actually the problem of some post- modernists, especially for Baudrillard.

Here, the problem found to be further analyzed in this novel is; Yann Martel's Life of Pi which told about two ambiguous and uncertain stories. It means that there is a hidden reality which is covered and it is exactly the problem should be taken as the important issue. Therefore, this study is actually trying to see this situation as one of postmodern fiction through simulation and hyper-reality. However, there is something should be added as an important case in this study since Yann Martel's Life of Pi is a literary work, it must be created by an author and the author has his own "real" reality in his imagination. Therefore, the imagination itself becomes the "real" or the Idea of the represented story. This imaginative source is continuously written down to be a story of the novel. To find it becomes the ground of how simulation and hyper-reality in this novel are started. As the background of the analysis is specified, two problems are about how is simulation understood in Yann Martel's Life of Pi? and what is the hyper-reality resulted as the impact of simulation represented in Yann Martel's Life of Pi?

\section{Simulacra, Simulation And Hyper-Reality}

Baudrillard explains about the Simulacrum and Simulation and presented the reader to see the case of Watergate (1972-1974) as an example. It is a term used to describe a series of political scandals in the United States that resulted in the resignation of President Richard Nixon and led to terrible constitutional crisis in the 1970s. The incident began with the arrest of five men who tried to break into an office complex of the Democratic National Committee to install some listening devices or wiretaps to spy. The incident, which occurs during the campaign, after investigation yet to be found that it is done by a group of Nixon's supporters; the Committee for the Selection Back President. Then, Nixon is sentenced guilty with no objection, he is forced to submit a letter of resignation as the president.

It is very interesting to realize that people know this case from media and all truths are under control by the media. Before this 
case, media represents this political very good until people do not realize the truths behind the media's representation. After the case, the media represents something oppositional such as the scandal, then people are angry because they feel to have been corrupted by the government. However, the question should be raised here is, "which one is the real truth?" Media has blurred the real reality through its representation and the representation replaces the real reality as if the representation is the real reality. Thus, Baudrillard claims that

"Watergate is not a scandal: this is what must be said at all cost, for this is what everyone is concerned to conceal, this dissimulation masking a strengthening of morality, a moral panic as we approach the primal (mise en) scène of capital: its instantaneous cruelty, its incomprehensible ferocity, its fundamental immorality - this is what is scandalous ..." (1994a: 29).

For Baudrillard, media has concealed the truth so the truth strengthens its moral power (that the politic is good one). People do not realize that they have been trapped and cheated by the representation. When media exposes the other side of the representation, people see it as scandal while the scandal comes at the very beginning of the representation. According to Baudrillard, the contemporary mass media presents a "dizaying whirl of reality" that is not a reflection of what "really happens" in the real world, but is rather a production of a simulated world in which "we live, sheltered by signs, in the denial of the real" (Baudrillard, 1998: 34). Baudrillard claims that people strive everywhere to find "the same stereophonic effect, the same effect of absolute proximity to the real, the same effect of simulation" (Baudrillard, 1994b: 6) so that "the entire history of man is in a gigantic simulation model' (1975: 33).

Basically, simulation is the imitation of the operation of a real-world process or system over time (Banks, et.al, 2001: 3). It is like a copy which is reproduced regularly until the original cannot be known. When people listen to mp3, they will not realize that the song is just the copy. People cannot distinguish the origi- nal and the copy song because the original song has been copied massively by the music studio. This is how the simulation chews and eats the real reality. Baudrillard takes Disneyland as the best example to see it;

"Disneyland is present as imaginary in order to make us believe that the rest is real, when in fact all of Los Angeles and the America surrounding it are no longer real, but of the order of the hyper-real and simulation. It is no longer a question of a false representation of reality (ideology), but of concealing the fact that the real is no longer real' (Baudrillard, 194a: 25).

The simple explanation toward Baudrillard's Disneyland is actually on the way the imaginative reality is presented as the real world. When people arrive at Disneyland, they will have no awareness that they stand on the real land. Because the real land is represented imaginatively, people do not realize the real so that the real is no longer real. This is how Baudrillard explains about the imaginative reality which is simulated and it becomes the hyper-reality and he writes;

"There is no longer any critical and speculative distance between the real and the rational. There is no longer really even any projection of models in the real ... but an in-the-field, here-and-now transfiguration of the real into model. A fantastic short-circuit: the real is hyper-realized. Neither realized nor idealized: but byper-realized. The byper-real is the abolition of the real not by violent distinction, but by its assumption, elevation to the strength of the model' (Baudrillard, 1983: 83-84).

The postmodernism, according to Baudrillard's analysis, marks the point at which the real reality has been completely replaced and transformed by rationalized, publicized and represented models and, as a result of this, the possibility of a critical and speculative about the distance between the real reality and the represented (imaginative) reality has collapsed. Hyper-reality is always together with simulation insofar as it is going with representation but does not represent something totally. Usually, representation starts from the principle that the 
signifying and the real reality are equivalent or can be connected. Conversely, simulation starts from something beyond this principle of equivalence and from the radical negation. It does not only copy but produce the new form representation. While representation tries to absorb simulation by interpreting it as false representation or false copy, the simulation covers the whole construction of representation. Those are called as a simulacrum or false copy.

There are three orders of simulacra; (1) the image is a clear imitation of the real, the image is recognized as just an illusion, a copy for the real, (2) order of simulacra, the distinctions between the real and the representation (copy) begin to break down, (3) the representation precedes and determines the real. There is no longer any distinction between real reality and its representation and there is only the simulacrum (Felluga, 2002, Purdue). These can be elaborated that the real reality firstly is represented and then the representation (the copy) masks and perverts the real reality. It also masks the unrepresented reality. Because it finally represents the imperfect reality, it means that the represented image of the reality has no relation to any reality. It is its own pure simulacrum in simulation or in the reproduction of an imitation. Here shown that there is a tight relation among simulacrum, simulation and hyper-reality.

\section{Representing Yann Martel's Life Of Pi As A Story: Pi's Animal Story in its Represen- tation}

Representation can be in any possible meanings, literally it refers to description about something. However this research is using Baudrillard's perspective, thus the meaning of representation will be limited only from the thinker's point of view. Representation in Baudrillard is dealing with simulacra and simulation, where reality is turned to symbols and signs.

Yann Martel's major part in Life of Pi is the story about Pi and the animals. It is told in detail as the major parts of the novel. So, Pi's animal story will be described in this part and it should be started with the characters. The characters that should be seen are $\mathrm{Pi}$ and the animals (the Zebra, the Orangutan, the Hyena and the Tiger or Richard Parker).

The zoo has to be relocated because Pi's father had agreed to sell the animals to Canada. Therefore, the only way to move the animals out is by storing them using ship cargo; in this case, Japanese cargo. The voyage is through Pacific Ocean. The ship called Tsimtsum was sailing off. Unfortunately, Pi and the others will face the worst thing they have not ever seen. When the night came up, the hard rain had fallen and it went into one huge storm that wrecked the ship. It shakes anything inside of the ship including the animals. Pi jumped out to the lifeboat and suddenly get dropped. He lost everything including his family. When Pi was sad, suddenly, a Zebra jumped and one of its legs hits the bar it gets broken. In this condition, the Zebra is hurt by the broken leg. "It had badly broken a rear leg [...] Bone protruded through skin and there was bleeding. Only its slim front legs had a semblance of normal position [...]" (Martel, 2012:136).

It is the portrayal of the moment when Pi found out that the zebra's leg was broken. Pi looked deeply at the zebra, for him that was the moment that made him so sad saw the injured zebra. Pi admired the zebra very much and he shows it by his description about the stripped color (black and white). This is the love from Pi for the patterns on the zebra's skin. He is amazed by the elegancy of it. This is the important issue that can take the significant part of the zebra as the representation of what Pi retells on his story. The plot and the characteristics around the zebra should be emphasized because it will guide the story to its representation. Something real behind the representation that builds the representation. The zebra jumped and then one of its legs was broken. That was the condition of the zebra one easily not to forget. In its detail, the zebra was hurt painfully and Pi looked at it pitifully. Therefore, this explanation or description can be very important to understand the representation and how the representation works to retell as the story.

After the zebra's representation based on Pi's perspective which create the true zebra 
that is injured, then it is continued by the representation of the hyena. After the zebra jumps out to the life boat, Pi sees that a hyena follows to jump out to the lifeboat, Pi looks to dislike to this animal and he tries to push the hyena out of the lifeboat by using the lifeboat's oar, but it does not work because the hyena avoids it. The hyena starts sneaks the blood on the zebra's leg then he eats it before eats the whole body of the zebra as it is described, "The zebra's broken leg was missing. The hyena had bitten it off and dragged it to the stern, behind the zebra [...]" (Martel, 2012: 150-151). Pi's perspective is constructed by the way it is put into a story, a narration and language. Therefore, it should be understood that the hyena's characteristics and actions are the representation of $\mathrm{Pi}$ as the narrator who retells what (never) happened to him on the sea. The points that should be considered here can be; (1) the hyena comes after the zebra, (2) the broken leg zebra is eaten by the hungry hyena, and (3) the way the hyena eats also shows the pitiless cruelty and the brutality. It also should be noticed that Pi represents the hyena as a cruel animal he dislikes it. He dislikes the hyena as hell and it will guide the representation of the story that will come up to simulation.

Actually, at the moment the hyena brutally ate the zebra, a female orangutan floated on a bunch of banana which is coming closer to the life boat at the morning as Pi describes; "She came floating on an island of bananas in a halo of light, as lovely as the Virgin Mary" (Martel, 2012: 139). It is different from how Pi describes the hyena, Pi seems to be amazed to the female orangutan. He describes her as the Virgin Mary. By understanding of his analogy about the Virgin Mary, it indicates something that should be noted. There is also important that should not be forgotten that Pi names the orangutan with Orange Juice as he exposes; "It was Orange Juice [...]" (Martel, 2012: 140). The bananas which Orange Juice rides do not sink because she rides on hundreds of kilos of banana and it rationally makes sense. This representation also functions to connect all parts the representations.

The hyena that had eaten the zebra drove orangutan angry. Orangutan's anger had disturbed hyena, so it killed orangutan afterward. The hyena, then became the greatest killer in Pi's lifeboat. Pi was surprised to find that there is a grown up tiger jumped out and attacked the hyena soon. The tiger killed and ate the hyena up. Pi becomes more frightened and he was just stuck at a moment seeing the brutality. The life of the hyena was over and now, Pi lives with this tiger, Richard Parker. It makes Pi thought something to stay alive. Pi made the small raft, because Richard Parker cannot swim so that he was safe on the raft. He also has to find food for Richard Parker because when Richard Parker is hungry, he can eat $\mathrm{Pi}$ alive. The last thing he has to think is that to tame Richard Parker, this also functions to keep Pi's mind from getting lost, frustrated and mad. This is what can be known from the story of $\mathrm{Pi}$ and the animals.

This representation concludes in one condition that Pi survives by seeing the brutality on a lifeboat. However, as it is mentioned before, the Japanese officials did not believe in his story, therefore they demanded some logical story although it is noted that Pi's story about himself and the animals is exactly the representation of his experience while the officials do not believe in it. The way they do not believe in the story because they want something more logical. It means that they know something they do not know clearly; the reality; the reality of how the shipwreck happened and how Pi could survive on it. But, the reality never exist or can never be presented wholly, all efforts to present it wholly and totally as if the experience comes in the present time are useless because it just ends it representation. The losing reality and the representation which is not trusted by the officials show the important thing that there is no reality and there is just representation of reality which is called as the simulacrum of the reality. All is retold is just the simulacra of the Pi's experience while the true story remains hidden somewhere nobody knows, even Pi because Pi also cannot present it totally as he has experienced. The story reduces the reality and all story are in words then words mislead the path to the truth. Thus, every truth is gone and what is known is just the false representa- 
tion of it. This way to produce and reproduce the reality in its representation is the simulation. To make it right, this animal story will be continued by the human story in this novel to erase the boundary of the true story.

\section{Pi's Human Story in its Representation}

Pi's story about the animals on the lifeboat seems too hard to believe, especially, for the Japanese officers who want rational and logical story. Then, Pi told another story that can be accepted by them. The other story Pi tried to tell is also about he and his life on the lifeboat but he survives from the cruelty of the Cook not the animals. After the shipwreck, Pi jumped out to a life boat, then the crewman (the oriental man) jumped that causes him to get injured on his foot. After that the Cook jumped out to the life boat with his disgusting appearance. When the morning comes, Pi's mother came closer on the lifeboat while she was floating on the bunch of bananas. The Cook had killed the crewman and by looking at this cruelty, Pi's mother got angry and tried to slap the cook. However, the cook had been out of control and he is unstoppable. He was eating the crewman in a brutally manner, while being smashed by the anger of Pi's mother, it drove the cook angry. Finally, he kills Pi's mother as he kills the crewman cruelly. Pi suddenly gets angry and he tries to kill the cook. Pi finally can finish the cook's life after the cook feels that it is the time for him to die.

Based on the short review of the human representation in Pi's story, it is noted that the first person came after Pi was the crewman, while Pi simulates him in this representation "The sailor was young [...] but he broke his leg jumping from the ship and his suffering made bim a child. He was beautifup' (Martel, 2012: 382-383). This amazement to the crewman/the sailor is similar to the amazement to the zebra on the other story. Therefore, it can be taken the important problem of this amazement that Pi actually has a good feeling to the sailor. He is pitied the sailor because of his broken leg. It also shows that Pi represented the sailor as the one he loves on the lifeboat.

Instead of presented the sailor, he presented the cook as the one whom he hated. It can be seen from "He was a disgusting man. His mouth had the discrimination of a garbage heap. He also ate the rat [...] He was such a brute, that cook, ill-tempered and bypocritical (Martel, 2012: 382). Pi shows that the Cook is a nasty person. The cook killed my mother" (Martel, 2012: 389). The Cook killed Pi's mother and this was the final brutality that he had done to the "passengers" on the lifeboat. This also concluded that the cook is like the Hyena which killed Orangutan. Pi told that his mother came closer to the lifeboat by floating on the bananas as it is shown on this quotation; "Mother held on to some bananas and made it to the lifeboat" (Martel, 2012: 382). It means that Pi's mother came to the boat on many bundles of bananas floating on the water like Orangutan did. After seeing the brutality of the cook;

"Mother slapped bim in the face, a full hard slap that punctuated the air with a sharp crack. It was something shocking coming from my mother. And it was heroic. It was an act of outrage and pity and grief and bravery" (Martel, 2012: 387).

This explanation of Pi's mother completes the whole characters which are represented by $\mathrm{Pi}$ in accordance of human story. This human story should be compared to the animal story to find the relation between the true story and the copy story. However, the problem will be still on the way the two stories can be true and can be both copy stories.

The most important that should not be removed is Pi himself. Pi represented himself as the character of himself in his own story. Pi was the one who killed the cook, "I put the hatchet down. I would break its neck, sight unseen, I decided. I wrapped the fish tightly in the blanket. With both hands I started bending it. The more I pressed, the more the fish struggled' (Martel, 2012: 231).

This is the confession of Pi Patel before he changed to be a horrific creature he had never been. Pi realized that his life is now similar with that of Richard Parker. He is no longer human who was a believer and good. He is Pi with the animal side now; brutal and cruel. This can be assumed as Pi's bad side of his life 
which is always hidden and covered by his religious morality. Then it is exploded out by being animal to survive and the way he eats is just the same way as Richard Parker does. Even when he has landed on Mexico's coast, when Richard Parker goes off, Pi feels that one of himself has been lost.

Pi fell in love with Richard Parker (his bad side of his life that he represents as the grown-up Bengal Tiger). He loves the side of his life because it keeps him alive in the survival on the Pacific Ocean lonely. He explained that "Something in me died then that has never come back to life (Martel, 2012: 321) He felt something is already dead within his side (the dead one is his cruel and brutal side). Thus, it concludes the major part of this representation that $\mathrm{Pi}$, during his survival has lived up his brutal side, but when he has landed, his brutal side has gone because Pi has to come back to his social live which is morally and ethically.

\section{Encountering Animal Story and Human Story}

Based on the explained points above, it can be understood that Richard Parker and Pi are similar, especially in the context of characteristics and the scene they shared within the story. With a certain point to be noted that Richard Parker can be the anger side of Pi after seeing his mother is killed. To make it easier to be read, this diagram can be seen as the importance of understanding about the two stories.

Pi told a story in a purpose to present the true story, however, the true story cannot be presented totally. Therefore, it was only representation that appeared in the end. The representation means presenting the particular part and it goes worse when it is known that it refers/copies the other representation. For example, Pi tells "bis story with the animals" which refer to "his story with human" and tells "bis story with the human" which refer to "bis story with the animals". On the other hands, the true story will never be presented totally and it means that there are just available for representations of it and the true story never exists. To continue this part, it should be followed on this below explanation about this case.

\section{Reading the Ambiguous Stories in Yann Martel's Life of Pi}

The simulation in a literary work can be seen through the representation that exposed previously. In order to see it, the primary things to be done are to understand and to know it clearly. Thus, the first thing to do is to see the aspects related to the representation, especially about what it is compared to. The important thing should be considered is the structure of the novel which are consisted of the narration of the novel and the characters involved in in the every conflicts.

It is known that Yann Martel's Life of $\mathrm{Pi}$ is the story of a boy who survives in a traumatic shipwreck for months in a lifeboat with a grown up Bengal tiger named Richard Parker. The beginning of the novel told about Pi's childhood and youth. His family owns a zoo in their hometown in India. Early in Pi's life, his father realized that his son's inexperience about the tiger can put $\mathrm{Pi}$ in danger. Then it is told that Pi also believes in a variety of religions; Hindu, Catholics, and Islam. His family can accept it although it seem hard for them. When $\mathrm{Pi}$ is a young boy, his family chose to sell the animals and move to Canada on a cargo ship named Tsimtsum. However, a terrible storm had happened during the voyage. Pi gets thrown out of the ship and gets into a lifeboat.

In the next morning, he found himself in the lifeboat with a seriously injured zebra, a cruel hyena and a mature orangutan named Orange Juice. Hiding under the canvas of the lifeboat, there was the Bengal tiger named Richard Parker. The hyena attacked and ate the zebra, then continue attacking and eating Orange Juice. The orangutan has a good effort to fight back but the hyena eventually slays her. Richard Parker finally jumpes out, killed and ate the hyena. There only remain Pi and Richard Parker surviving on the lifeboat after that.

Pi recognized that he must survive and think of something because Richard Parker will always certainly seek a chance to eat him. He rapidly understands that dehydration will also kill him sooner than hunger or the tiger's attack, so he thinks of it and he notices the supplies stored in the lifeboat, including biscuits, water 
and its purifiers, a whistle and a handbook for surviving at sea. With those stuffs, Pi builds a small watercraft or raft, made of oars and lifejackets, which is tied to the lifeboat so that he can jump out when Richard Parker is suddenly out of control. He thinks of a variation of survival options and he decided to tame the tiger although he cannot totally control Richard Parker.

The way he tamed Richard Parker are by blowing a whistle and shaking the lifeboat to make the tiger seasick. With that way, Pi can calm Richard Parker down and protect his own territory on the lifeboat against Richard Parker. After that, Pi finally discovered an island, which made of trees, roots, leaves and plants while in the mid of the land, there is a small lake with fresh water. But, Pi finds a fruit-bearing tree and when Pi peels back the layers of a piece of fruit, he finds that it contains a human tooth. He assumed that the land is a carnivorous land, eating everything that lives on it. Pi and Richard Parker return to the lifeboat to sail the ocean (again). An uncertain amount of time had passed, then Pi and Richard Parker land on a beach in Mexico. Richard Parker runs into the busses and he is gone. Pi is brought to a hospital and given some food.

Several days had passed, he is interrogated by two officials from the Maritime Department in the Japanese Ministry of Transportation. They did not believe Pi's story about his survival with the animals. They ask for more logical story that can be accepted rationally. Then, Pi offers them another story which is fairly similar story. The things left unchanged are shipwreck and a lifeboat. Pi shared the lifeboat with a broken-leg oriental crew of the sunken ship, his mother and a French cook who ultimately slays and eats both Pi's mother and the oriental man. Pi went mad and he then stabs the French cook in the throat and watched him dying. Pi eats the French cook's flesh with anger furiously. This second story seems to satisfy the officials' cynicism, but they still do not believe in it at all. They admit to Pi that his second story of surviving with the tiger on the lifeboat is a better story, while the true story still remains uncertain. This story exposes some important points that has to be taken at a glance, because this can be the important components for showing how the narration of the story becomes the process of representations which are simulated.

Pi experienced a shipwreck, he survives on a lifeboat. There are animals on the life boat; zebra, orangutan, hyena and tiger. Those animals are told and narrated by the narrator, which means that the story is flash back. In this re-told story, what things elaborated is the representation of the narrator or Pi himself. It needs to be considered that Pi's real experience is the real one, but this real experience cannot be presented wholly, there is just available for presenting in representation. The story is the representation and it is the copy of something real. The copy of the real must be different because it is represented in language while language has no fully meaning; it is the chain of signifiers which offer ambiguity in chasing its fully meaning. Therefore, what things should be said in this case is that Pi's story is the simulacra because it copies something cannot be copied in the total sameness. There is always different thing, there is always missed thing and there is always something unrepresented. It means that the representation must be dissimilar or different to the real experience which has been passed. This simulacrum is produced and reproduced along the story goes on.

This simulation is not only once produced, the representation which is false is reproduced again when the Japanese officials need another story. The problem is their disbelief which makes Pi represents another representation of his unattainable real experience. Another story is the shipwreck and a lifeboat. Pi survives on it with an oriental crewman, his mother and Pi himself. It is not only the representation of their existence, but is also their conflicts and their characteristics. As it is known that the zebra is represented to have an injury on his leg while the oriental crewman is also represented to have the injury on his foot. The orangutan is represented as female and she comes floating on a bunch of bananas while Pi's mother is also represented to come floating on a bunch of bananas. The hyena is represent- 
ed as a brutal one while the French cook is also represented as a brutal one.

The representations are combined into one simulation which makes chaos to its reality. All are representations and the representations take the reality away and make the representations as the reality on its own. Hyena eats the zebra and them orangutan while the hyena is eaten by the tiger. The French cook eats the crewman and kills Pi's mother while Pi kills the French cook. The conflicts are same and connected to each other. But, the problem is actually on how those should be seen as just the representations of something unknown. The unknown things are the reality behind its representation. This just becomes the simulation and the representation is the simulacra.

After determining these two similar stories, thus it can be known that the two stories show its truth and the truth is that those are just representation. Those are just the simulacra of how copying processes in representation which are far different from what is represented. The difference is not kind of thing that can be seen clearly but it can be known from how the stories give the ambiguities. The real story cannot be known, it is unknown reality which has been passed and cannot be reproduced in total same. The author's imagination is never caught it is just represented without the whole presence.

The simulation here means that a story is constructed by representations while the representations are always lack and flaw. Therefore, it is just simulacra from the false copy of the represented world or author's imagination. In this novel, the simulacrum is the first story consists of animals and Pi. This representation has been already the false representation or false copy, it is the simulacrum. This false representation is continuously encountered and mixed with another representation which is also false. Those combinations finally make the distorted story becomes more distorted story. If a story is false representation, this will be more false representation if the story is encountered with another story which has similar story and conflicts. Finally these important stories becomes the great elements to understand why these are said as the simulation of the false representations or simulacrums which are reproduced when the story is told and going on.

\section{Conclusion}

Yann Martel's Life of Pi contains of two stories which is told by the protagonist, $\mathrm{Pi} \mathrm{Pa}-$ tel. The great problem which is put in this novel is the two stories, because the two stories are connected to each other and the two seem similar. Moreover, the two stories are telling similar characteristics of each character, so it assumes that the two stories refer to each other. Referring means the story tries to present the true story behind what it is told and the problem is, the true story is presented representatively from another story.

Two stories are in one situational story. The first story (animal story) refers to another story (human story) and the human story refers to the first story (or the first taken story-the animal story). Therefore, the two story is just trying to represent another story to present, as if, the whole or the total true story, while it is unrepresented totally.

The way the story refers to each other without referring to the true story means that the true story cannot ever be presented, or it has to be said that there is no true story and the available story is just the represented story which is simulacra. The simulacra condition is sourced by the way it copies another story rather than copying the true story. Therefore, the result must be far different from the true story and of course, there is no true story. Thus, every story is just simulacra and it is simulated as a story. This simulation (as a process) result the reality beyond the true reality (the true story) and it is what should be said as the hyper-reality. Yann Martel's Life of Pi ultimately delivers the hyper-reality behind its simulation in the two simulacra stories.

\section{Refferences}

Banks, J. et.al. 2001. Discrete-Event System Simulation. Upper Saddle River: Prentice Hall.

Baudrillard, Jean. 1975. The Mirror of Production (trans. Mark Poster). St. Louis: Telos. 
Baudrillard, Jean. 1983. In the Shadow of the Silent Majorities: Or, the End of the Social and Other Essays (trans. Paul Foss, et.al.). New York: Semiotext(e).

Baudrillard, Jean. 1994b. The Illusion of the End (trans. Chris Turner). Cambridge: Polity Press.

Baudrillard. Jean. 1994a. Simulacra and Simulation (trans. Sheila Faria Glaser). Ann Arbor: University of Michigan Press.

Baudrillard. Jean. 1998. The Consumer Society: Myths and Structures. London: Sage.

Lyotard, Jean-Francois. 1984. The Postmodern Condition: A Report on Knowledge. Minneapolis: University of Minneapolis Press

Lyotard, Jean-François. 1992. The Postmodern Explained (trans. Don Barry, et.al.). Minneapolis: University of Minneso- ta Press.

Martel, Yann. 2001. Life of Pi. New York: Houghton Mifflin Harcourt.

\section{Online Refferences}

Felluga, Dino. 2002. Modules on Baudrillard: On Simulation. Introductory Guide to Critical Theory. Purdue, retrieved from http:/ / www.purdue.edu/guidetotheory/postmodernism/modules/baudrillardsimulation.html, on 22 September 2015, at $11 \mathrm{am}$.

Krist, Gary. 2002. Taming the Tiger. The New York Times, retrieved from http:// www.nytimes.com/2002/07/07/ books/taming-the-tiger.html, on 20 September 2015, at 8 am. 